\title{
Evaluating the impact of budgetary control on the performance of MDA's in Bauchi state Nigeria: Case study of ministry of budget and planning Iliya Garba' and Isah Gambo ${ }^{2}$
}

${ }^{\prime}$ Department of Accounting, Faculty of Arts and Social Sciences, Gombe State University, PMB 127, Gombe, Nigeria

²Abubakar Tatari Ali Polytechnic, PMB 005, Bauchi State, Nigeria

\begin{abstract}
This study evaluate the impact of budgetary control on the performance of MDA's in Bauchi state was conducted using ministry of budget and planning as a case study. Spearman's rank correlation statistical tools were employed for data analysis. Cognitive evaluation theory is used for the study, which suggests that when looking at a task, we evaluate in term of how well it meets over needs to feel in competent and in control. Finding of the hypotheses tested and the direct interview conducted reveals that planning, goal recognition and accountability all had strong positive relationship on the performance of MDA's in Bauchi State. The results show that there is positive relationship between all the tested hypotheses under discussion. The paper recommend that, organizations should give more impetus to planning as it is the bases of most progress that most organization. Managers are to be proactive as it is what is required in planning and since budgeting and budgetary control contribute to the improvement of management efficiency and high productivity, the budget committee should be educated in the implementation of budget. Thus a budget education should be conducted at least once a year by the financial or independence accounting or management consulting firm. Its usefulness cannot be question or over emphasized.
\end{abstract}

Key words: Bauchi, Budget, Control, Performance, Nigeria

\subsection{Introduction}

Government use budgets as a guiding tool for planning and control of its resources, be it financial or otherwise. The use of budget involves knowing how much money you earn and spend over a period, particularly one year (Abdullahi and Angus, 2012). As we are all aware, the basic responsibility of government is to improve the living International Journal of Accounting \& Business Finance 30 condition of the citizens. The government has to raise sufficient money to finance its operations and provide good services for which it is responsible (Ikpe and Oba, 2004). It is through the budget that government informs the citizens what it intend to do to improve the economic, social and political wellbeing of the people within the next one 
year (Beatrice and Thuo, 2013). This study is intended to evaluate the impact of budgetary control on the performance of MDA's in Bauchi State, A case study of ministry of budget and Planning.

\subsection{Objectives of the study}

The main objective of this study is to evaluate the impact of budgetary control on the performance of MDA's in Bauchi state ministry of budget and planning. However, the specific objectives are:

(i). To evaluate the impact of planning on the performance of Bauchi state ministry of budget and planning.

(ii). To determine the relationship between goal realization and the performance of Bauchi State ministry of budget and Planning.

(iii). To ascertain the relationship between accountability and the performance of Bauchi State ministry of budget and Planning

\subsection{Research hypotheses}

H1: Planning affects the performance of MDA's in Bauchi state ministry of budget and planning.

H2: Goal realization affects the performance of MDA's in Bauchi state ministry of budget and planning.

H3: Accountability has effect on the performance of MDA's in Bauchi state ministry of budget and planning.

H4: Coordination has effect on the performance of Bauchi state ministry of budget and planning.

\subsection{Theoretical approach}

Frederickson \& Fredrikson (2006) Assert that in budget issue, cognitive evaluation theory has been the proffered and must cited theory for understanding resources allocation decisions and budgetary outcomes. Cognitive evaluation theory provide a framework for providing how budget decisions are derived from the interaction and gathering of information by individuals attempting to minimize utility for various purpose within an institutional setting. This theory suggests that when looking at a task, we evaluate in term of how well it meets over needs to feel in competent and in control. If we think we will be able to complete the task. We will be intrinsically motivated to complete the task requiring no further external motivation.

\subsection{Literature review}

It is well recognized that an organization should be managed effectively and efficiently. Managing, in fact, implies coordination and control of the total enterprise efforts to achieve the organizational objectives. The process of managing helps management charts its course in advance (Suberu, 2010). The functions of management also include decision making facilities by various managerial techniques procedures and by utilizing the individual and group effort in a coordinated and ration way. Organizations have limited resources and these limited resources impose limit on the number and range of goals that the organization can hope 
to attain. One systematic approach for attaining effective management perform ance is profit planning or budgeting. Profit planning or budgeting is an integral part of management. The controller would be particularly interested in profit planning since it helps to regulate flows of fund which is this primary concern.

According to Pandy (1985) states that common organizational goals includes maximizing profits and achieving satisfactory level of performance and performing a social service by providing goods and services desired by others. It is with a view of achieving their organizational goals that great emphasis is placed on budgeting. The budgeting process may be quite formal in a large organization with committees set up to perform that task. On the other hand in a small firm the owner jot down his budget on a piece of scrape paper or even on the back of a used envelope, some even manage without writing anything down at all they have done the budget in their heads and can easily remember them. When a plan is expressed quantitatively it is known as budget and the process of converting plans into budget is known as budgeting. Budgeting therefore is essentially a process of planning and control. He argues that a well prepare budget provides management with a planning programme based on investigation study and research on the part of the entire organization.

The word "budget" is said to be derived from the French word "Budget" which means "Bag" ( Bag of money) and also from the Latin word "Bulga" meaning "Purse" (Knap sack) and come to be associated with chancellor of the exchequer's bag which contains annual estimate of the country's income and expenditure in the national budget. The chancellor is concerned with planning, co-coordinating and controlling income and expenditure for the government.

Siyaubola (2013) opines that growing complexity of the business environment and the ever increasing competition among firms in the modern time make planning an invaluable tool for business success. Successful management is no longer just a matter of flair skills and determination, a conscious effort is needed to harness available resources towards the achievement of enterprise objectives. He says that budgeting is one of the tools adopted by management for effective cost planning and control.

Abullahi (2015) defined budget as a plan expressed in quantitative and usually monetary terms for a specific period of time. Normally the period covered is one year and this makes it a short term plan. Practically all large organization both in the private and public sectors prepare annual budgets. He is of the view that budget is a short term financial planning which guides manager in achieving the objectives of a firm. Munir (2014) argues that budget is a quantitative expression of a plan of action prepared in advance of the period to which it relates. Budgeting may be prepared for the business as a whole, for department, for functions such 
as sales production or for financial and resources items such as cash capital expenditure manpower purchase etc. The process of preparing and agreeing budgeting is a means of translating the overall objectives of the organization into detailed feasible plans of actions. This is usually prepared for a stated period of time usually one year. A budget may be prepared simply using paper and pencil or on computer using spread sheet program like excel or with a financial application like quicken or quick books. A budget as defined by institute of cost and management Accountants "ICMA" is a financial statement prepared and approved prior to a defined period of time of the policy to be pursued during that period for the purpose of attaining a giving objective.

Adams (2009) is of the view that budget is a future plan of action for the whole organization or section thereof. Budget can also be defined as a financial statement of the sources (revenues) and uses (expenditure) of fund of the government. It is prepared by the minister of finance in case the of federal government and commissioner of budget and planning in the case of state government and then presented to the parliament for discussion and approval. It is unlawful to spend government fund without the approval of the parliament. The budget is an important economic development which reveals the state of the economy and the expected future trends

\subsection{Types of budget}

Each revenue and expenses activities of an International Journal of Accounting \& Business Finance organization can be budgeted. There are several types of special purpose budgets which can be graded in respect of its attributable functions. They include:

i) Time perspective - long term and short term budget.

ii) Function factor - sales budget, selling and distribution cost budget, production cost budget, purchase budget, personnel budget, research budget capital budget, office and administration, budget plant utilization budget, cash budget.

iii) Flexibility factor - Fixed budget and flexible budget (iv) Zero Base Budget (ZBB) (v) Rolling Budget (vi) Activity Based Budgeting (vii) Incremental Budget (viii) Planning Programming Budgeting System (PPBS)

\subsection{Major types of budget in government}

Government's spending profile and the desired level of economic activity will to a great extent determine the type of budget to be executed by the government in any given period.

There are three main types of government budget:

(i) Balance budget (ii) Deficit budget (iii) Surplus budget. The level of economic activity of an economy can take the form of prosperity, recession, depression and recovery.

\subsection{Conditions for effective budgetary control system}

The following are some of the conditions for effective budgetary control system thus: are as follows

i). involvement and support of top 
management

ii) Clear cut information on long term corporate objectives within which the budgeting system will operate

iii). Realistic organizational structure with clearly define responsibility

iv). Regular revision of budget and targets where necessary

\subsection{Methodology}

The method adopted by the researcher is administration of direct questionnaire; inquiries were also made both directly and indirectly through some unusual questions to both the staff and the management of the ministry.

\subsection{Research design}

The type of research design used in this research was (hypothesis testing) to explain the phenomenon of the relationship between the variables, types of relationship between the variables of this study was causality. The type of research data was subject data in the form of opinion, attitude, and experience of a person ( Rustam, 2017), sources of research data was primary inform of respondents perception and the instrument used was questionnaire.

\subsection{Population of the study}

For the purpose of this study; the staffs of the ministry were used as the population. Though the populations consist of mainly of public servants, the members of the population differed in their professional and occupational groupings. The numbers of staff in the ministry were in total of 94 .

\subsection{Data collection technique}

The data collection technique is the questionnaire which was directly distributed to the respondents. The respondents have answered the questions posed on the questionnaire on five likert rating.

\subsection{Data presentation, analysis and} discussion of findings

Table 1 Details of Questionnaire

\begin{tabular}{ccc}
\hline $\begin{array}{c}\text { Particulars of } \\
\text { questionuaire }\end{array}$ & Frequency & Percentage \\
\hline $\begin{array}{c}\text { Number of questionnaire } \\
\text { adinistered. }\end{array}$ & 94 & 100 \\
$\begin{array}{c}\text { Number of questionnaire } \\
\text { retrieved }\end{array}$ & 84 & 89.36 \\
$\begin{array}{c}\text { Number of questionnaire } \\
\text { not returned }\end{array}$ & 10 & 10.64 \\
$\begin{array}{c}\text { Number of questionnaire } \\
\text { wrongly filled }\end{array}$ & 8 & 9.52 \\
$\begin{array}{c}\text { Number of usable } \\
\text { questionnaire }\end{array}$ & 76 & 90.48 \\
\hline
\end{tabular}

Research survey, 2017

From Table 1, it is observed that 94 questionnaire were administered to respondents. 10 questionnaire representing 10.64 percent were not returned. 84 questionnaire representing 89.36 percent were returned. However, out of this number only 76 questionnaire representing 90.48 percent were correctly filled and thus suitable for data analysis.

\subsection{Demographic analysis}

In this study the output of the demographic analysis are presented. These presentations would further enable the understanding of demographic distribution of the sample. 
Table 2 Indicate your Gender

\begin{tabular}{cccccc}
\hline & & $\begin{array}{c}\text { Frequenc } \\
\mathrm{y}\end{array}$ & $\begin{array}{c}\text { Perce } \\
\text { nt }\end{array}$ & $\begin{array}{c}\text { Valid } \\
\text { Perce } \\
\text { nt }\end{array}$ & $\begin{array}{c}\text { Cumulati } \\
\text { ve Percent }\end{array}$ \\
\hline Vali & Male & 52 & 68.4 & 68.4 & 68.4 \\
$\mathrm{~d}$ & $\begin{array}{c}\text { Femal } \\
\text { e } \\
\text { Total }\end{array}$ & 24 & 31.6 & 31.6 & 100.0 \\
& 76 & 100.0 & 100.0 & \\
\hline
\end{tabular}

Source: Research Data November 2017, (SPSS output version 21.0)

\subsection{Bivariate analysis}

In determining the statistical technique to suit our purpose, we considered (Kothari, 2004) who argued that when there exists association or correlation between two variables, correlation technique should be used and when there exists cause and effect relationship between two variables in the case of the bivariate population or between one variable on one side and two or more variables on the other side in case of multivariate population, partial correlation technique is appropriate. This was the basis for our choice of the Spearman Rank Oder Correlation to test our hypothesized relationships in our study. This section will therefore be used to present answers to our hypotheses

\subsubsection{Scatter Plot of the relationship between study variables}

According to Neuman, (2000) (cited in Asawo, 2009), Scatter graph is one of the techniques used in deciding whether a bivariate relationship does exist between interval scaled variables. In our bid to determine the existence and trend of this relationship, we plotted a scatter diagram as presented in Figure 1. Budgetary control as an independent variable is plotted on the $\mathrm{X}$ axis whereas MDA performance as the dependent variable is on the $Y$ axis.

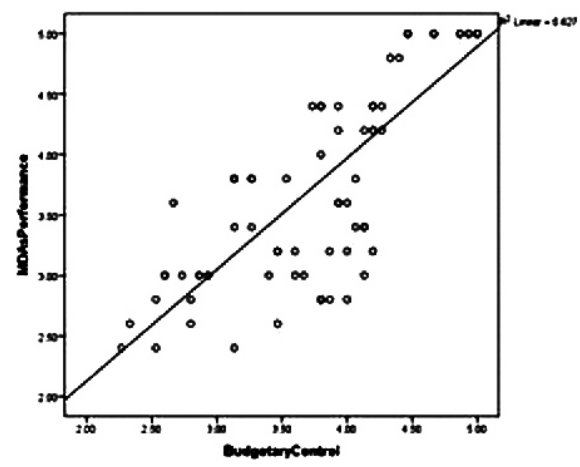

Figure 1 Scattered plots for budgetary control and MDA performance.

The apparent pattern of the cases in the scatter plot sloping upwards from left to right is an indication of existing linear and positive relationship between budgetary control and MDAperformance.

\subsection{2: Presentation of results on the} Analysis of data and testing of hypotheses.

We had proposed three hypotheses in the study to seek explanation to the budgetary control and MDA performance. The Spearman rank order correlation coefficient is calculated using the SPSS 21.0 version to establish the relationship among the empirical referents of the predictor variable and the criterion variable. We used this to answer research questions one to nine. Correlation coefficient can range from -1.00 to +1.00 . The value of -1.00 represents a perfect negative correlation while the value of +1.00 represents a perfect positive 
correlation. A value of 0.00 represents a lack of correlation. In testing hypotheses one to three, the following rules were upheld in accepting or rejecting our null hypotheses: all the coefficient values that indicate levels of significance $(*$ or $* *)$ as calculated using SPSS were rejected and therefore our alternate hypotheses accepted; when no significance is indicated in the coefficient $r$ value, we reject our alternate hypotheses. Our confidence interval was set at the 0.05 (two tailed) level of significance to test the statistical significance of the data in this study.

\subsubsection{1: Relationship between budgeting} planning and MDAs performance

Table 3 below shows the result of correlation matrix obtained for Job design and workers' commitment. Also displayed in the table is the statistical test of significance ( $p$ - value), which makers us able to answer our research question and generalize our findings to the study population.

Table 3: Correlations matrix between budgeting planning and MDAs performance

\begin{tabular}{|c|c|c|}
\hline & $\begin{array}{c}\text { Budget } \\
\text { Planning }\end{array}$ & $\begin{array}{c}\text { MDAs } \\
\text { Performance }\end{array}$ \\
\hline $\begin{array}{l}\text { Correlation } \\
\text { coefficient }\end{array}$ & 1.000 & $\begin{array}{l}-338^{* *} \\
-003\end{array}$ \\
\hline Budgeting Plannin & & \\
\hline $\begin{array}{l}\text { Sig.(2-tailled) } \\
\mathrm{N}\end{array}$ & 76 & 76 \\
\hline $\begin{array}{l}\text { Spearman's rho } \\
\text { Correlation } \\
\text { coefficient }\end{array}$ & $\begin{array}{c}-338^{* *} \\
-003\end{array}$ & 1.000 \\
\hline $\begin{array}{c}\text { MDA's } \\
\text { Performances (2- } \\
\text { tailled) } \\
\mathrm{N}\end{array}$ & 76 & 76 \\
\hline
\end{tabular}

** Correlation is significant at the 0.01

level (2-tailled)

Source: Research data June 2017, (SPSS output version 21.0)

Table 3 illustrates the test for the first previously postulated bivariate hypothetical statements. The results show that for

$\mathbf{H a}_{1:}$ There is significant relationship between budgetary planning tool and ministry performance $(\mathrm{r}=0.338, \mathrm{p}=$ $0.000<0.01$ );

Therefore based on the results illustrated, for the previous bivariate alternative hypothetical statements are hereby accepted as the study finds that:

$\mathbf{H a}_{1:}$ There is a significant relationship between budgetary planning tool and performance of Bauchi State ministry of budget and planning.

\subsubsection{2: Relationship between goal realization and MDAs perfor- mance}

Table 4 below shows the result of correlation matrix obtained for goal realization and MDAs performance. Also displayed in the table is the statistical test of significance ( $p$ value), which makers us able to answer our research question and generalize our findings to the study population. 
Table 4: Correlations matrix between goal realizations and MDAs performance

\begin{tabular}{ccc}
\hline & $\begin{array}{c}\text { Goal } \\
\text { Realization }\end{array}$ & $\begin{array}{c}\text { MDAs } \\
\text { Performance }\end{array}$ \\
\hline $\begin{array}{c}\text { Correlation } \\
\text { coefficient }\end{array}$ & 1.000 & $.692^{* *}$ \\
Goal Realization & & .000 \\
Sig.(2-tailled) & 76 & 76 \\
$\mathrm{~N}$ & & \\
$\begin{array}{c}\text { Spearman's rho } \\
\text { Correlation } \\
\text { coefficient } \\
\text { MDA's }\end{array}$ & $.692^{* *}$ & 1.000 \\
$\begin{array}{c}\text { Performances (2- } \\
\text { tailled) }\end{array}$ & 76 & \\
$\mathrm{~N}$ & & 76 \\
\end{tabular}

** Correlation is significant at the 0.01

level (2-tailled)

Source: Research Data June 2017, (SPSS

output version 21.0)

Table 4 illustrates the test for the second previously postulated bivariate hypothetical statements. The results show that for:

$\mathbf{H a}_{4}$ : There is a significant relationship between goal realization and MDAs performance $(r=0.692, p=0.000<$ $0.01)$,

Therefore based on the results illustrated, second previous bivariate alternative hypothetical statements are hereby accepted as the study finds that:

$\mathbf{H a}_{4}$ : There is a significant relationship between goal realization and performance of Bauchi state ministry of budget and planning.

\subsubsection{3: Relationship between accountability and MDAs performance}

The result of the Spearman's rank order correlation coefficient for the relationship between accountability and MDAs performance is presented in Table 5. The same table also gives the statistical test of significance ( $p$-value), which enables us to answer the next research question and at the same time, make generalizations.

Table 5: Correlations matrix between accountability and MDAs performance

\begin{tabular}{ccc}
\hline & $\begin{array}{c}\text { Goal } \\
\text { Realization }\end{array}$ & $\begin{array}{c}\text { MDAs } \\
\text { Performance }\end{array}$ \\
\hline Correlation & 1.000 & $.901^{* *}$ \\
coefficient & & .000 \\
$\begin{array}{c}\text { Goal Realization } \\
\text { Sig.(2-tailled) } \\
\mathrm{N}\end{array}$ & 76 & 76 \\
$\begin{array}{c}\text { Spearman's rho } \\
\text { Correlation } \\
\text { coefficient } \\
\text { MDA's }\end{array}$ & $.901^{* *}$ & 1.000 \\
$\begin{array}{c}\text { Performances (2- } \\
\text { tailled) } \\
\mathrm{N}\end{array}$ & 76 & \\
& & \\
\end{tabular}
level (2-tailled)

Source: Research Data November 2017, (SPSS output version 21.0)

Table 5 illustrates the test for the three previously postulated bivariate hypothetical statements. The results show that for:

$\mathbf{H a}_{7}$ : There is a significant relationship between accountability and MDAs performance $(\mathrm{r}=0.901, \mathrm{p}=0.000<$ $0.01)$

Therefore based on the results illustrated, third previous bivariate alternative hypothetical statements are hereby rejected as the study finds that: 
$\mathbf{H a}_{7}$ : There is a significant relationship between accountability and performance of Bauchi state ministry of budget and planning.

\subsection{Discussion of major findings}

Finding of the hypotheses tested and the direct interview conducted reveals that planning, goal recognition and accountability all had strong positive relationship on the performance of MDAs in Bauchi state.

\subsection{Summary of findings, conclusion and} recommendation

\subsection{Summary of findings}

The idea which necessitated this study was evaluating the Impact of budgetary control on the performance of MDAs in Bauchi state, a case study of ministry of budget and planning. In order to undertake this inquiry objectively, there were research hypothesis raised that reflected the dimensions of budgetary control to include planning, goal realization and accountability. From the data generated and analyzed, it was empirically discovered that a positive relationship exists the independent and dependent variables. Furthermore the study found that:

1. There is a positive relationship between planning and financial control in MDAs in Bauchi state.

2. There is a positive relationship between goal realization and financial control in MDAs in Bauchi state.

3. There is a positive relationship between accountability and financial control in MDAs in Bauchi state.

\subsection{Conclusions}

Based on the findings obtained from summary of discussion and empirical study we concluded thus:

1. Planning has an important role to play on financial control on MDAs in Bauchi state.

2. Goal realization significantly influences financial control on MDAs in Bauchi state.

3. Accountability significantly influences and financial control on MDAs in Bauchi state.

\subsection{Recommendations}

Based on the findings of the study, the following recommendations are hereby made:

Organizations should give more impetus to planning as it is the bases of most progress that most organization. Managers are to be proactive as it is what is required in planning That budget plan and preparation should be cooperate duty of the unit heads in the MDA's in Bauchi state.

That budget committee should budget well in order to control expenditure in the Ministry of budget and planning because without budgeting well the MDA's will keep spending money without meaningful achievement for it.

Adherence to the budgeting and budgetary control should be practice by top management. If they make arbitrary action the realization of the budget goal would be impossible.

Since budgeting and budgetary control contribute to the improvement of 
management efficiency and high productivity, the budget committee should be educated in the implementation of budget. Thus a budget education should be conducted at least once a year by the financial or independence accounting or management consulting firm. Its usefulness cannot be question or over emphasized.

\section{References}

Malgwi, A. A., \& Unegbu, A. O. (2012). Budget in Nigerian public sector: Need for balanced scorecard perspective. International Journal of Finance and Accounting, 1(2), 1-6.

Abdullahi, S.R \& Kuwata, G (2015) .The Role of Budget and Budgetary Control on Organizational Performance: Case Study of Tahir Guest House Kano. International Journal of Innovative Research and Security 4(2) 22-34

Chartered Institute of Management Accountants (2000), Management Accounting Official Terminologies, CIMA

Lucey, T. (2008), Costing, New York, DP Publications

Rustam, F.(2017) Influence of Local Government Performance: Budget control and Organizational Structure. European Research Study Journal 20(3) 580-593

Osisoma. B.C. (2000). Studies in Accounting; Afritower Limited
Pandy, I.M., (1985). Element of Management Accounting, Vikas Publishing House Limited

Ikpe, D.N. \& Obah, G.S. (2004), Management Accounting an Introduction Test. Lagos, Masdoc Publishers.

Beatrice, N. W. and Thou, V. W. (2013). Assessing Budgeting Process in Small and Medium Enterprises in Nairobi's Central Business District: A Case Study of Hospitality Industry. International Journal of Information Technology and Business Management, 17(1), 1-11.

Fredericson, D.G \& Frederikson, H.G (2006). Measuring the performance of hollow state. Wa s h ington D.C: Georgetown University Press.

Suberu, S.B. (2010). Budgeting Strategies in Nigeria. Samaru Journal of Information Studies. 10(1): 1-7

Siyaubola, T. T (2013) The Impact of Budgeting and Budgetary Control on the Performance off Manufacturing Company in Nigeria. Journal of Business Management and Social Science Research 2(12), 8-16

Munir, R.\& Ama, P. (2014). Association between Performance Measurement Systems and $\mathrm{O} r \mathrm{~g}$ a $\mathrm{n}$ i $\mathrm{z}$ a $\mathrm{t}$ i o $\mathrm{n}$ a 1 Effectiveness. International Journal of Operations \& Production Management, 34(7), 2-8 